Amnesic shellfish poisoning (ASP) is caused by domoic acid produced by certain species of diatoms. Although domoic acid has been detected in shellfish in California, no cases of ASP have been reported in the state.

Other human illnesses caused by toxins in shellfish include diarrhetic shellfish poisoning (DSP), caused by okadaic acid and its derivatives produced by algae in the genera Dinophysis and Prorocentrum, and neurotoxic shellfish poisoning (NSP), caused by brevetoxins produced by Gymnodinium breve.

CDHS provides current updates on marine toxin activity in California, which can be accessed by telephone (510/540-2605 or 800/553-4133).

\section{Seafood safety compendium}

As part of our Seafood HACCP Alliance activities, we have developed the Compendium of Fish and Fishery Product Processing Methods, Hazards and Controls. The Compendium includes sections on seafood processes and controls, as well as biological, chemical and physical hazards and controls. It provides the seafood industry with information on documented seafood process parameters, federal guidelines and tolerances for seafood contaminants, bacterial growth parameters and recommended hazard control options. The Compendium will assist the seafood industry in developing effective HACCP plans by providing scientific information on food-safety hazards and controls. It is available for viewing or downloading on the Internet (http://www-seafood. ucdavis.edu/haccp/compendium/ compend.htm). Research results on histamine prevention and control, as well as other hazards and controls, will be added as new information is published.

In projects funded by the U.S. Department of Agriculture, and in cooperation with Sea Grant programs in North Carolina and Alaska, we have developed HACCP food safety guides for delicatessens and for the musselprocessing industry (Price et al. 1993; Price et al. 1995). A publication entitled Ensuring Food Safety - The HACCP Way was cited by the

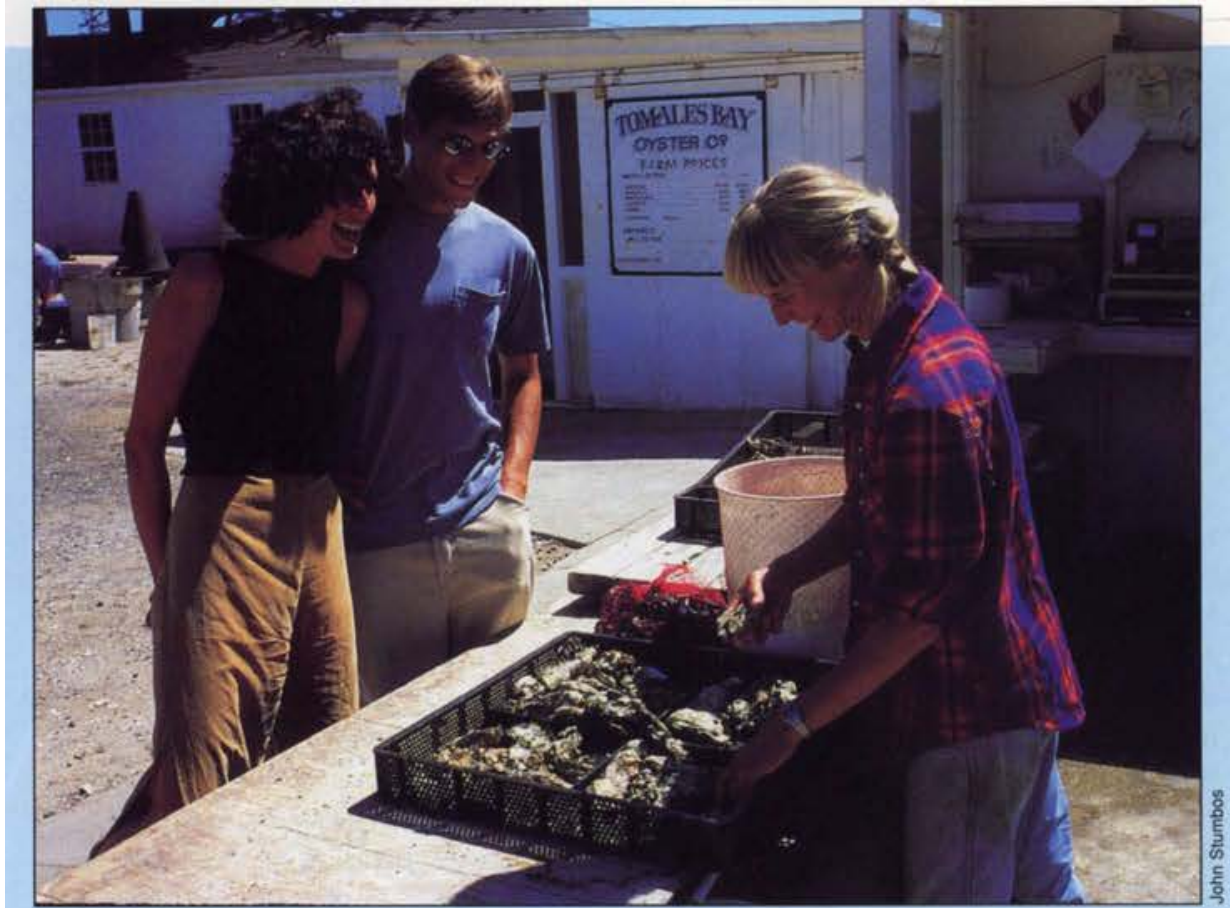

The oyster culture industry has been a part of Marin County's agriculture since the turn of the century.

\title{
Aquatic and land-based agriculture share vital water resources
}

\author{
Paul G. Olin
}

Tomales Bay and the surrounding watersheds provide a window into efforts to improve coastal water quality by controlling nonpoint-source pollution. A variety of programs are helping to maintain viable livestock and dairy operations in coastal Marin County, while keeping water quality high enough to support the oyster culture industry that has been a part of the region's agriculture since the turn of the century.

Nonpoint-source pollution - ranging from agricultural runoff to chemical pollutants washed into storm drains from urban areas - is a major factor in the deterioration of coastal water quality throughout the developed world. Shellfish are especially vulnerable to coastal water pollution because they filter their food from the water and can thereby concentrate pollutants in their tissues. In Tomales Bay, bacteria carried in runoff from livestock operations have caused interruptions in shellfish harvests immediately following heavy winter rains.

Oysters are frequently eaten raw on the half-shell, making contamination with bacterial or viral pathogens a serious concern. The Food and Drug Administration, in conjunction with individual states, operates the National Shellfish Sanitation Program to ensure that oysters and the waters they are grown in are free of harmful bacteria levels. In California, oyster-growing waters are monitored by the State Department of Health Services for total and fecal coliform bacteria, which may indicate potential sewage contamination. Coliform bacteria exist in the intestinal tracts of warm-blooded animals and birds, and are commonly found in soil and water. Fecal coliforms are common in the digestive tracts of warm-blooded animals and birds. 
Oyster-growing waters are approved for harvesting when total coliform counts are below a geometric mean MPN (most probable number) of 70 organisms $/ 100 \mathrm{ml}$ of water and fecal coliforms are below a geometric mean MPN of 14/100 ml. In Tomales Bay, these numbers can be exceeded after heavy winter storms when surface runoff carries bacteria from the land into coastal waters. Half an inch of rain in a 24-hour period results in a harvest closure for 4 to 5 days. During these short closures the oysters naturally purge themselves and are once again safe to consume raw. At no time is there any risk from consuming these oysters if they are cooked. During particularly wet winters, shellfish leases can be closed to harvest for considerable periods.

Concern about the effects of coastal water pollution on the oyster industry led to passage of the State Shellfish Protection Act in 1992. Under the act, technical advisory committees are formed to identify and remediate sources of pollution that result in closure of shellfish harvesting for more than 30 days per year. In 1994 the Tomales Bay Shellfish Technical Advisory Committee was formed. The committee designed and conducted a water quality study of the bay during 1995 and 1996.

The study results identified a number of watersheds, where the primary activities are livestock and dairy farming, that contribute substantial coliform loads to the oyster-growing waters of Tomales Bay. Although animal agriculture is polluting Tomales Bay, the overall effects of livestock operations on water quality are of lesser magnitude than those of alternate uses, such as high-intensity agriculture and residential and commercial development, and the oysters readily cleanse themselves so they are safe to consume after a short period. Oyster growers are committed to working with agricultural land owners to identify problem areas and develop practices that will improve water quality and allow both animal agriculture and oyster culture to continue into the next century. For their part, agricultural landowners are working proactively with UC Cooperative Extension and Sea Grant advisors to identify and improve water quality problems on their land. With funding from the Marin Community Foundation, Marin and Sonoma counties Cooperative Extension Director Ellie Rilla developed the Marin Coastal Watershed Enhancement Project to facilitate and support the landowners' efforts.

The project is helping landowners develop local approaches to controlling nonpoint-source pollution. Agriculture and marine advisors conduct workshops on water quality and ranch planning to teach landowners about water quality concerns and how to test water on their property. Advisors then help landowners develop ranch plans that describe ongoing conservation activities and identify additional efforts needed to further reduce nonpoint-source water pollution.

There are a variety of management practices that can minimize the effects of cattle and other livestock on water quality. The main issue is to keep livestock from having regular access to streams so that their manure is deposited on land well away from the stream beds. Ranchers may need to develop alternate livestock watering stations away from streams; adopt new grazing practices for riparian pas-
Oyster growers are working with agricultural landowners to identify problem areas and to develop practices that will improve water quality and allow both animal agriculture and oyster culture to succeed.

tures; encourage the growth of riparian vegetation along stream corridors; and avoid having areas of high animal density, such as feeding areas, near stream courses.

These efforts will help to improve water quality and ensure that livestock and dairy farming can coexist with oyster farming, using common water resources.

P.G. Olin is Marine Advisor, UC Sea Grant Program, Sonoma County Cooperative Extension. 